Miscellaneous

Papcr No. 1
Stare of Rlaska

Department of Natural resources DIVISJON OF MINES \& MINERALS

Box 1391, Juneau, Alaska 99801

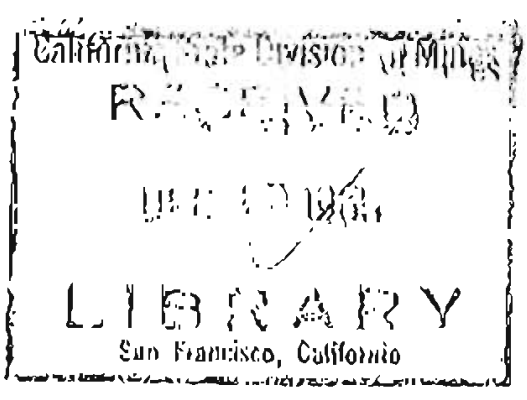

May 19, 1964

\title{
THE GREAT ALASKA EARTHQUAKE, MARCH 27, 1964
}

Late in the afternoon on Good Friday, March 27, 1964, one of the largest earthquakes ever witnessed by modern man occurred in Alaska. This great earthshock and resultant landslides and tsunaini (seismic sea waves) wrought devastation in many of the cities and towns of south central Alaska. killing 114 persons and causing an estimated $\$ 750,000,000$ in property damage.

Earthquakes are natural and recurring geologic phenomena resulting from movement along faulis in the earth's crust. Although earthquakes occur the world over, they are more frequent in zones of active mountain building, such as the zone around the Pacific Ocean along which a major part of the state of Alagka lies. In response to forces deep within the earth, the rocks in these active rones are under constant stress and are slowly being warped and folded. Should the stress exceed the strength of the rocks, the rocks ingtead of bending, break suddenly along a fault surface and an earthquake is generated. The Great Alaska Earthquake was only the culmingtion of a long period of increasing stress beginning many years ago deep beneath the waters of Prince William Sound.

The following preliminary data on the Great Alaska Earthquake have been made available by various seismograph stations throughout the United States:

Origin time: 5:36:14 PM, Alaska Standard Time, March 27. 1964

Epicenter 1/: Near college Fiord along north shore of prince William sound $\left(61.0^{\circ} \mathrm{N}\right.$. Lat., $147.7^{\circ} \mathrm{W}$. Isong.)

Depth: Approximatoly 20 miles

Magnitude $2 /: 8.4$ to 8.6

The earthquake was felt throughout half the state of Alaska and at loast as far goutheast is seattie, Washington, an ared of more than $1,000,000$ square miles. In Anchorage and other towns near the epicenter, exceedingly İ/Epicenter: - Point on the carth's surface directly above tho bxeak or earth. quake focus.

2/Magnituode: Mensure of energy released by earthquake. Scale ia logarithmic! hence a magnitude $\theta$ earthquake is relatively 10 times strongcr! than a magnitude 7 earthquake. 
strong ground motion continued from i to 4 minutes.

No evidence of the Eault, along which the break and earthquake occurred, has been observed at the earth's surface. Presumably the fault is aloping and intersects the surface under the waters of Prince william Sound south of the epicenter. The distribution of the epicenters of the hundreds of aftershocks which followed the major earthquake also indicate that the surface trace of the fault is submarine and describes an arcuate path extending from the mouth of Prince william Sound to south of Kodiak. Island.

Principal damage in Alaska was caused by the landalides and tsunami triggered or generated by the earthquake. Lesser damage is attribuatable to tho actual strong rolling ground motion of the earthquake shear waves.

In Anchorage, Alaska's largest clty, landslide movoment devastated large sections of the downtown business and suburban resldential districts. All the slides occurred in glacial sediments along steep bluffo facing Knik $\pi \mathrm{rm}$ and the streams flowing into Knik Arm. The slides moved mainly laterally with little or no vertical movement or rotation. The plane along which the slides moved is apporently a nearly liquid, water-saturated layer in the Bootlegger Cove clay which lies at shallow depths under much of the City of Anchorage. The largest of the Anchorage slides in the exclusive Turnagain residential district moved more than 200 acres of ground including over 100 homes as far as 500 fect out into Knik Arm. The slides in downtown Anchorage moved a maximum of about 15 foct and damage was restricted to the narrow pullaway trough at the head of the slides and the buckled compression ridges along the too.

South of Anchorago landglides and roek alides did consiclerable damago to the Alaska Railroad between Anchorage and sewara and the Anchorage-Seward Fighway. In the seaport towns of scward and Valdez large submarine landslides ard the local large waves generated by them destroyed much of the commercial waterfront districts. At Homer a small submarine landslide caused the disappearance of the small boat harbor, and at whittier a disturbance of unknown origin in the bay damagod dock facilitics.

Tsunamis, commonly but incorrectly called tidal waves, are longperiod water wavcs generated by the submaxine displacement of a large volume of water. The tsunami formed by the Great Alaska Earthquake was principally responsible for the heavy death toll. Hardest hit were the towns of Whitcier, Chenogar, seward, and kodiak. At Chenoga, where 27 people were killed, the largest wave was roported to be 90 feot high. The tsunami also damaged Valdez and other towrs in Prince Willlam sound and towns along cook Inlet. Outside of Alaska tho tsunami still contained dostructive energy ag far distant a.s Croscent City, California and Hilo, Hawali.

The strong ground motion of the carthquake severely damaged many 
structures, railroad beds, highways and bridges throughout the epicentral region. Tall office and apartment buildings in Anchorage were subjected to strong swaying with resultant structural damage. Poorly constructed buila. ings and many buildings in the process of constructionwere destroyed.

Regionally, a large areo of Alaska has subsided and a smaller area. clcvatod as a result of the carthquake. The land Exom Anchorage southwest to Kodiak Island and including most of the Kenei peninsula has subsided as much as 6 feet. East of this zonc, incluaing much of the prince william Sound area, the land has risun as much as 10 feet. Low-lying towns and many miles of highway and railbed have been covered by hj.gh tides in the subsidence arca.

The Groat Alagka Earthquake is awosome testimony to the powerful forces bound within the earth. Unlcashed, these forces have brought death to scores of people and devastation to their cities. However, these phenomena are the consoquence of natural geologic process which will continue to reshape the earth in the future. We cannot hide from or prevent these powerEul forccs, but can loaxterom expericnces such as this to minimize the dangox by taking proper precaltions: in the location and construction of our communitios. 


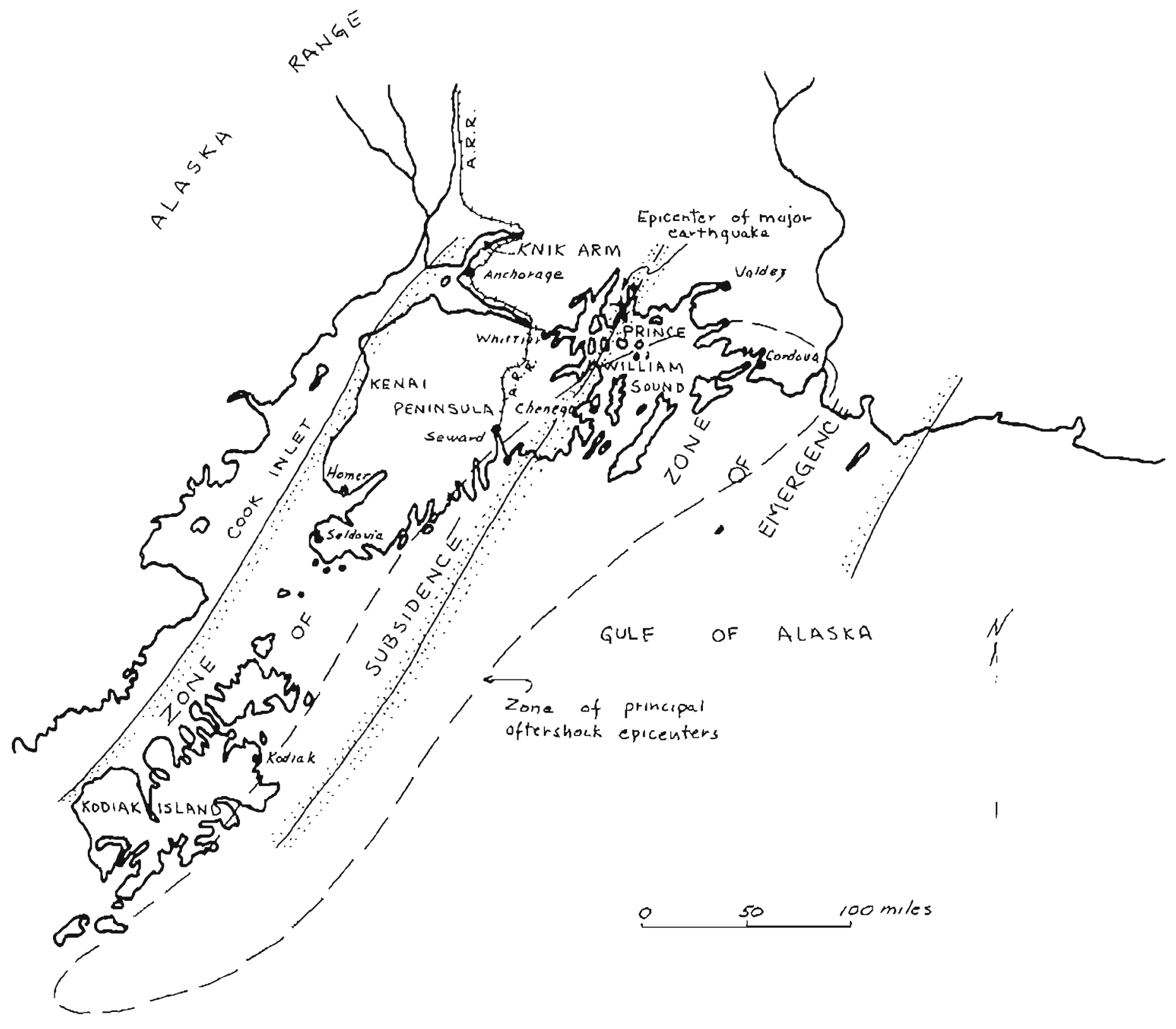

Map of south central Alaska showlng some of the regional effects of the Great Alaska earthquake and localities mentioned in text. 